\title{
Performance Model of Nurse Community Approach to Organizational Culture in Indonesia
}

\author{
Suhartono ${ }^{1}$, Sulistiawati ${ }^{2}$, Esty Yunitasari ${ }^{3}$ \\ ${ }^{1}$ School of Nursing, Nahdlatul Ulama Institute of Health Science, Indonesia \\ ${ }^{2}$ School of Madical, Airlangga University, Indonesia \\ ${ }^{3}$ School of Nursing, Airlangga University, Indonesia
}

\begin{tabular}{l} 
Article Info \\
\hline Article history: \\
Received Jun 12, 2016 \\
Revised Aug 12, 2016 \\
Accepted Aug 26, 2016 \\
\hline
\end{tabular}

\section{Keyword:}

Nurse community approach Organizational culture Regression test Skills and abilities

\begin{abstract}
National problem faced by Indonesia today is the handling of the low quality of Human Resources (HR). HR issues that need attention is the issue of performance. Performance is the rate of success in carrying out the task, as well as the ability to achieve the goals set. The aim of this study was to determine the influence of individual factors, organizational factors, organizational and cultural factors on the Performance of Nurses. This study used a cross sectional study approach. The population used in this study were nurses ponkesdes Tuban and Lamongan district in accordance with the inclusion criteria as much as 55 , with a sample size of 48 respondents specified research using simple random sampling technique. The independent variable in this study is the individual factors (abilities and skills), organizational cultural factors and organizational factors, dependent variable is the performance of nurse ponkesdes. Instruments used in the collection of data in the form of questionnaires and performance evaluation sheet. Research analysis using simple linear regression test. Simple linear regression analysis showed variable organizational cultural factors were not statistically significant effect on the performance of the p-value $(0.000)$, organizational factors also significantly influence the performance of the pvalue (0.027). While the variable factors of individual (skills and abilities) does not significantly influence the performance of the p-value (0.103).
\end{abstract}

Copyright (C) 2016 Institute of Advanced Engineering and Science. All rights reserved.

\section{Corresponding Author:}

Suhartono,

School of Nursing,

Nahdlatul Ulama Institute of Health Science,

Indonesia.

Email: arto.suhartono@yahoo.com

\section{INTRODUCTION}

Performance problems occurred not only in the government agencies but also private agencies that are experienced educated people. It is also experienced by health agencies in Indonesia ranging from central to local levels, ranging from the hospital to the village health center (ponkesdes).

Performance issues will impact the vast and dangerous for the long term. Not only have an impact for the health authority, but also has implications for society. On health agencies could happen for example health centers planned program was not carried out optimally, the less people feel the benefits of the ponkesdes. Here is an issue which will certainly hamper the development of health if it does not respond and did not immediately dealt with properly. Many things can affect the performance, to the agencies should strive to ensure that the factors relating to the performance can be met to the fullest. One effort that can be done to improve the performance of nurses ponkesdes is to approach organizational culture.

Approach organizational culture is a common perception held by members of the organization, and is a system of shared meaning, which has the characteristics of innovation, namely the extent to which 
employees are encouraged to be innovative and take risks. The attention to detail things that is the extent to which employees are expected to exhibit precision, analysis and attention to detail. Results orientation, namely the extent to which management focuses on results rather than on the techniques and processes used to achieve these results. People orientation that is the extent to which management decisions take into account the effects on people within the organization. Team orientation that is the extent to which work activities are organized around teams, not individuals. Aggressiveness is associated with aggressiveness employees. Stability emphasizing retention of organizational culture is good.

\section{RESEARCH METHOD}

The study design used is cross sectional study. The population in this study were nurses ponkesdes Tuban and Lamongan district in accordance with the inclusion criteria as much as 55, with a sample size of 48 respondents specified research using simple random sampling technique. The independent variable in this study is the individual factors (abilities and skills), organizational cultural factors and organizational factors, while the dependent variable is the performance of nurse ponkesdes. Instruments used in the collection of data in the form of questionnaires and performance evaluation sheet. Research analysis using simple linear regression test. The conceptual framework of this study is shown in Figure 1.

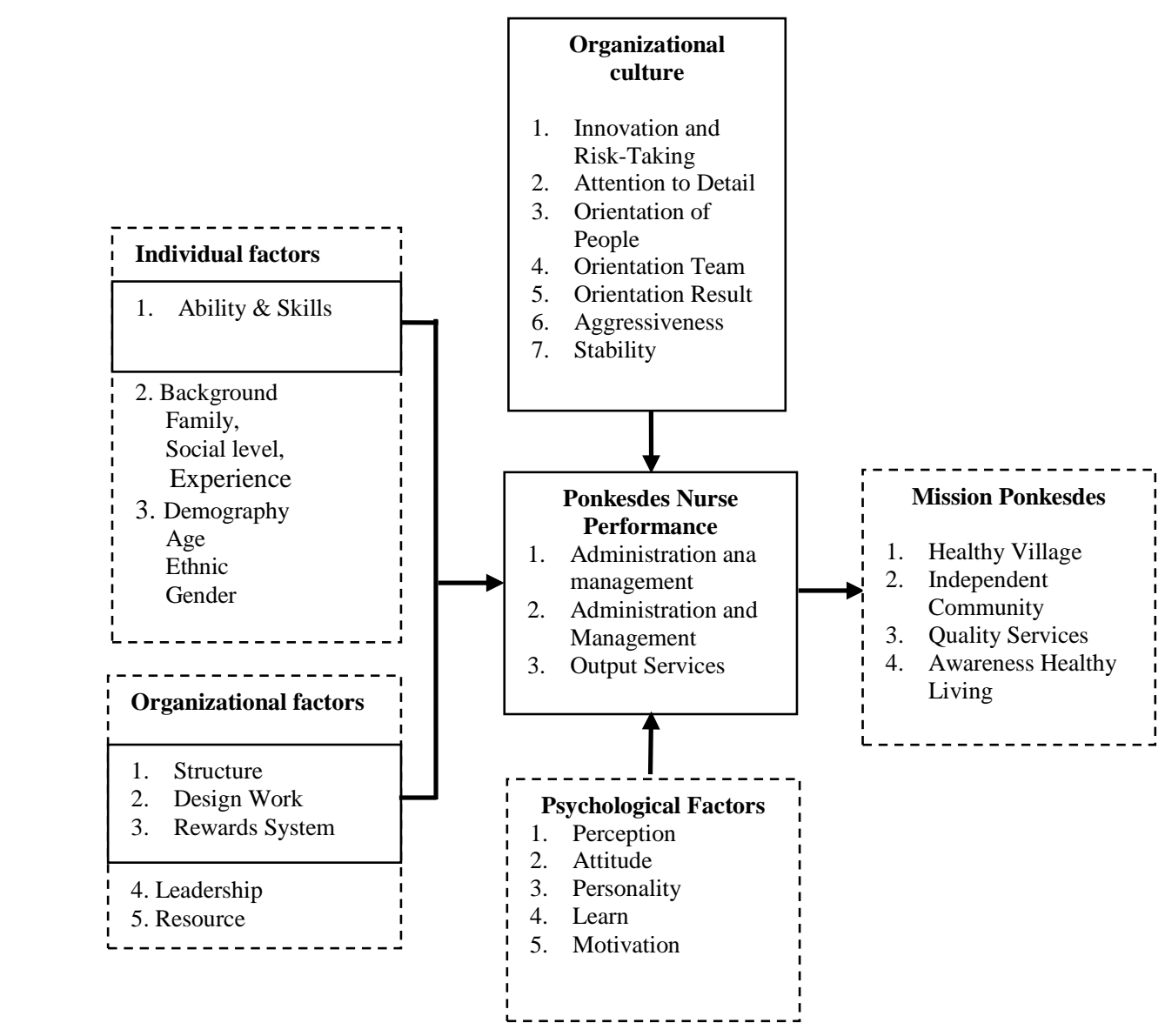

where : $\square$ investigated.

Figure 1. Conceptual Framework Performance Model of Nurse Community approach to Organizational Culture.

This study tried to approach organizational culture in addressing performance issues. Organizational culture is a system of values and beliefs that are shared by members of an organization that distinguishes the organization from one another " 


\section{RESULTS AND ANALYSIS}

Table 1 shows the majority of respondents have sufficient performance, respondents who have performed reasonably and has individual factors (abilities and skills) pretty much as 25 respondents (52\%), respondents who have a strong performance and organizational factors (structure, job design and reward system ) pretty much as 22 respondents (46\%), while respondents who have sufficient performance and sufficient organizational cultural factors as much as 26 respondents (54\%). There are also respondents who have performed well and have individual factors (abilities and skills) either by 8 respondents (17\%), respondents who have a good performance and organizational factors well as seven respondents (14\%), respondents who coined the good performance and good organizational factors as well as seven respondents (14\%). But there is one respondent who have less performance but have good organizational factors, this is because the respondent education levels S1 and nurses, as well as working lives long enough, so it may affect his knowledge in the organization. While its performance is less because he works in a place far from health centers, support infrastructure that is lacking, and the lack of local awareness related ponkesdes function.

Table 1. Distribution of cross-individual factors, organizational factors and factors of organizational culture on the performance of nurses ponkesdes

\begin{tabular}{ccccccccccc}
\hline \multirow{2}{*}{ Performance } & \multicolumn{3}{c}{ Individual factors } & \multicolumn{3}{c}{ Organisation factors } & \multicolumn{3}{c}{ Organizational Culture Factors } \\
& Good & Enough & Less & Good & Enough & Less & Good & Enough & Less \\
\hline Good & 8 & 3 & 0 & 7 & 4 & 0 & 7 & 4 & 0 \\
\hline Enough & 8 & 25 & 0 & 10 & 22 & 1 & 6 & 26 & 1 \\
\hline Less & 0 & 4 & 0 & 1 & 1 & 1 & 0 & 1 & 3 \\
\hline
\end{tabular}

\subsection{The effect of individual factors on the performance of nurses ponkesdes}

Tables 2 and 3 show sumarry model and coefficient in this study, respectively. Table 3 shows that the value of $p=0.103(p \geq 1)$ means the individual factors (abilities and skills) does not affect the performance.

Table 2. Summary Model

\begin{tabular}{ccccc}
\hline Model & $\mathrm{R}$ & $\mathrm{R}-$ Square & Adjusted R-Square & Std. Error the Estimate \\
\hline 1 & .238 & .057 & .036 & 11.71768 \\
2 & .000 & .000 & .000 & 11.93510 \\
\hline
\end{tabular}

Table 3. Coefficients

\begin{tabular}{|c|c|c|c|c|c|c|c|c|}
\hline & \multirow[t]{2}{*}{ Model } & \multicolumn{2}{|c|}{$\begin{array}{l}\text { Unstandardized } \\
\text { Coefficients }\end{array}$} & \multirow{2}{*}{$\begin{array}{c}\text { Standardized } \\
\text { Coefficients } \\
\text { Beta }\end{array}$} & \multirow[t]{2}{*}{$\mathrm{T}$} & \multirow[t]{2}{*}{ Sig. } & \multicolumn{2}{|c|}{ Collinearity Statistics } \\
\hline & & B & Std. Error & & & & Tolerance & VIF \\
\hline \multirow{2}{*}{1} & & 29.983 & 20.369 & & 1.472 & .148 & \multirow{3}{*}{1.000} & \multirow{3}{*}{1.000} \\
\hline & (constant) F_ındividual & .461 & .277 & .238 & 1.661 & .103 & & \\
\hline 2 & (constant) & 63.707 & 1.723 & & 36.981 & .000 & & \\
\hline
\end{tabular}

The results showed that most respondents have individual factors (abilities and skills) in the category enough, the majority of respondents also sedangan performance in the category enough. But the results of statistical analysis showed that individual factors (abilities and skills) does not affect the performance of nurses ponkesdes. This can be possible because the researchers only see the individual variables of the capability and skills alone, while according to Gibson in the measurement of performance behavior, individual factors besides views of abilities and skills, also look at the background and demographic individual.

Gibson Ivancevich explains that the factors that affect performance are the factors of the individual variables consisting of abilities and skills, background, and demographics. Factors affecting the performance of the latter is a factor of psychological variables consisting of perceptions, attitudes, personality, motivation, job satisfaction and job stress. While the third factor is a factor that affects the performance of an organization consisting of resources, leadership, compensation / remuneration, organnisasi structure and design work [1].

Based on the theoretical basis and see the results of the research that besides the ability and skills in the individual variables there are also factors that can affect the performance ie the background and demographics [1]. Where background includes family, social level and experience. Families may affect an individual's performance because of many factors or problems that there are in the family such as economic, 
social, and so forth. While the social level also needs to be factored in the effect on performance, it can be possible that the level of social good individual performance is also good. Then the experience is an aspect that is important to look at the impact on individuals, with long work experience that may allow an individual's performance is getting better [1].

While demographic factors including age, ethnicity, and gender is a factor to be considered in addition to the background of individuals in their influence on performance. Age may affect performance, with increasing age, the individual will increase the knowledge, insight and experience that will affect the performance of individuals. For ethnicity and gender is also necessary to study its effect on performance. Although in this study the individual factors do not have a significant influence on the performance, but the individual factors still need to be considered in the study are to do with performance, because in this study in the taking of individual factors as variables the study only look at factors abilities and skills, do not look at background factors and demographic individual [1].

Meanwhile to see descriptions of the behavior of specific individuals, Gomes describes several dimensions or criteria that need attention in measuring performance, among other things: the quantity of work is the amount of work done within a specified time period, the quality of work is quality work achieved under the terms of suitability and readiness, job knowledge is the breadth of knowledge and skills on the job. Creativeness is the authenticity of the ideas raised and measures to resolve the problems that arise, Cooperation is the willingness to cooperate with other fellow members of the organization, Dependability is awareness and trustworthy in terms of attendance and completing the work, the Initiative is a passion for carry out new tasks and to enlarge its responsibilities, personal qualities are related to personality, leadership and personal integrity [2].

\subsection{The influence of organizational factors on the performance of nurses ponkesdes}

Table 4 shows that the $\mathrm{R}^{2}$ value of 0.102 means that organizational factors can explain or predict the value of the variable performance of $10.2 \%$. The remaining portion of $89.8 \%$ is explained by factors other than organizational factors. Durbin Watson value of $(\mathrm{D}=2.176)$, whereas in the table $\mathrm{dU}=1.5776$, then (DW $>d U$ ) shows that there is positive autocorrelation, which is a requirement to use linear regression. It means that this model can be used to explain the influence of organizational factors on performance.

Table 4. Summary Model

\begin{tabular}{cccccc}
\hline Model & R & R-Square & Adjusted R-Square & Std. Error the Estimate & Durbin-Watson \\
\hline 1 & .320 & .102 & .083 & 11.43086 & 2.176 \\
\hline
\end{tabular}

Table 5. Coefficients

\begin{tabular}{|c|c|c|c|c|c|c|c|c|}
\hline & \multirow{2}{*}{ Model } & \multicolumn{2}{|c|}{$\begin{array}{l}\text { Unstandardized } \\
\text { Coefficients }\end{array}$} & \multirow{2}{*}{$\begin{array}{c}\text { Standardized } \\
\text { Coefficients } \\
\text { Beta }\end{array}$} & \multirow[t]{2}{*}{$\mathrm{T}$} & \multirow{2}{*}{ Sig. } & \multicolumn{2}{|c|}{ Collinearity Statistics } \\
\hline & & B & Std. Error & & & & Tolerance & VIF \\
\hline \multirow[t]{2}{*}{1} & (constant) & 42.357 & 9.473 & & 4.471 & .000 & & \\
\hline & F_organization & .323 & .141 & .320 & 2.289 & .027 & 1.000 & 1.000 \\
\hline
\end{tabular}

Table 5 shows that the value of $p=0.027$ means that organizational factors affect the performance. While the columns are collinearity Statistics VIF $=1$ means not occur multikolinieritas, meaning there is the influence of organizational factors on performance.

The results showed that the frequency of organizational factors most respondents in the category enough, while the performance of the majority of respondents also in the category enough. Results of statistical analysis show that organizational factors (structure, details of the task, and the reward system) significantly affects the performance of nurses ponkesdes (management and administration, service process, and output services).

Keban explains that the achievement of performance results can be assessed according to the perpetrator, namely, the individual performance that illustrates how far a person has been carrying out a duty that can deliver results that have been set by the group or agency, the group's performance that illustrates how far a person has duties principally so that it can deliver results that have been set by the group or agency, the performance of the organization which illustrates how far the group has carried out all the activities of the subject so as to achieve the vision and mission of the institution, program performance that is related to how far the activities in the program that has been implemented so as to achieve the objectives of the program [3].

Good performance in an organization should be supported by the ability of individuals to understand an organization itself. Individuals should be able to understand the structure of the agency halted from structure to tasks within the organization. As a nurse working in ponkesdes must understand and appreciate 
the system in the work place organization. With an understanding of the organization, the nurse would be more appropriate and optimal in carrying out their duties in accordance with the performance. In this study, said most of the respondents have the ability to organize in enough categories, it may be possible respondents have college level education, scientific study and experience in organization during the lecture [3].

\subsection{The influence of organization cultural factors on the performance of nurses ponkesdes}

Table 6 shows that the $\mathrm{R}^{2}$ value of 0.980 means the organizational cultural factors can explain or predict the value of a variable performance by $98 \%$. The remaining $2 \%$ is explained by factors other than organizational cultural factors. Durbin Watson value of $(\mathrm{D}=2.209)$, whereas in the table $\mathrm{dU}=1.5776$, then $(\mathrm{DW}>\mathrm{dU})$ shows that there is positive autocorrelation, which is a requirement rather than linear regression. It means that this model can be used to explain the influence of organizational culture on performance.

Table 6. Model Summary

\begin{tabular}{cccccc}
\hline Model & R & R-Square & Adjusted R-Square & Std. Error the Estimate & Durbin-Watson \\
\hline 1 & .990 & .980 & .980 & 9.26097 & 2.209 \\
\hline
\end{tabular}

Table 7. Coefficients

\begin{tabular}{cccccccc}
\hline \multirow{2}{*}{ Model } & \multicolumn{2}{c}{$\begin{array}{c}\text { Unstandardized } \\
\text { Coefficients } \\
\end{array}$} & $\mathrm{B}$ & Std. Error & $\begin{array}{c}\text { Standardized } \\
\text { Coefficients } \\
\text { Beta }\end{array}$ & $\mathrm{T}$ & \multicolumn{2}{c}{ Sig. } & \multicolumn{2}{c}{ Collinearity Statistics } \\
Tolerance & VIF \\
\hline Organizational culture & .876 & .018 & .990 & 47.984 & .000 & 1.000 & 1.000 \\
\hline
\end{tabular}

Table 7 shows that the value of $p=0.000$, meaning that cultural factors affect the performance of the organization. While the column there is collinearity Statistics VIF $=1$ means not occur multikolinieritas, meaning that there are cultural factors influence organizational performance.

The results showed that most respondents have a factor of organizational culture (innovation and risk taking, attention to details, people orientation, team orientation, results orientation, aggressiveness, and stability) in the category enough, while the result of statistical analysis showed that cultural factors organizations (innovation and risk taking, attention to details, people orientation, team orientation, results orientation, aggressiveness, and stability) strongly affected the performance of nurses ponkesdes (management and administration, service process, and output services). Means the better nurse organizational culture, the better the performance of nurses ponkesdes.

The results support the theory Robbins stated that organizational culture can improve employee performance, especially if the seven factors that shape the organizational culture (innovation and risk taking, attention to details, people orientation, team orientation, results orientation, aggressiveness, stability) is accepted as the values that must be adhered to, believed and implemented wholeheartedly, so that will give birth to an organizational culture that will have an impact on improving employee performance [4].

Some research related to cultural organizations that have made other researchers to prove that organizational culture is very important and plays an important role for the progress of an organization. Some research in Indonesia, proving that organizational culture has a significant influence on employee motivation by Hamid [5]. Research conducted Sumardjoko which is the object of the study was college, showed that the organizational culture variables have the greatest contribution to the lecturer's role in quality assurance [6]. Soedjono research results explains that there is a significant influence of organizational culture on organizational performance [7].

Research Kotter and Heskett, Chatman and Bersade say that organizational culture has an influence on employee performance, organizational culture can produce effects that affect individuals and the performance, especially in a competitive environment, this influence can even be greater than all the other factors [8]. While Harvey and Browin found only companies with effective culture that can create increased productivity, increase the sense of ownership of the employees and ultimately improve the company's profit by Moeldjono [9]. Peters and Waterman research showed stronger culture of the organization, employees will be more results-oriented. When employees understand the organization's culture, they know what is expected of them. Here the core values serve as the foundation that supports and guide employee behavior related to their duties by Mangkunagara [10].

Robbins describes how the culture of an organization is built and maintained. The original culture was shown on the philosophy of its founder, then this culture greatly affects the criteria used in hiring employees. Actions of top management defines the general climate of good behavior is acceptable or not. However employees are socialized, the level of success achieved will depend on the suitability of the values 
espoused by new employees with the organization's values in the selection process as well as the preferences [4].

An organization usually formed to achieve a certain goal through the performance of all existing human resources within the organization. However, the performance of human resources is determined by the condition of internal and external environment of the organization, including the organization's culture [4]. Therefore, the ability to create an organization with a culture that is able to push performance is a requirement by Wibowo [11]. While Noe and Mondly see that organizational culture is an integral part of a set of processes or devices to achieve the mission and goals of the organization. Thus, the formation of a powerful organizational culture, adaptive and transformative is a step in the strategic and tactical management to build the organization on an ongoing basis. Thus organizational culture that enables individuals to interact and integrate. Interaction and integration in addition to creating a sense of belonging will also enable organizations constantly learn to adapt and interact with development environments by Tika 2006 [12]. In accordance with the opinion of Robbnis stating that the employee's performance is a function of the interaction between the abilities and motivation. If one less then the performance will be negative. Intelligence and skills need to be considered in addition to the motivation to explain accurately the performance of employees [4].

Riani suggests the presence of the organization's culture will allow employees to adjust to the environment of the organization, and help employees to determine what action should be done in accordance with the values that exist within the organization and uphold these values as a guide employees to behave which can be run in carrying out its duties and work. Nurses who have good organizational culture and know the benefits, then the performance of nurses will keep running continuously well [13]. That will create effective organizational environment. Organizational culture becomes very important, so it is necessary to improve the organizational culture in order to optimize the role of nurses. With good organizational culture nurse will demonstrate its ability to the task in hand, with innovation, success orientation and good performance stability associated with the duties of a nurse ponkesdes, and has a high loyalty to duty as a nurse so that will affect performance.

\section{CONCLUSION}

Approach organizational culture can be a reference DHO in improving health worker performance in the working area of health districts of Tuban and Lamongan. The approach can be applied in organizational culture and performance of nursing duties acted upon everyday, so it can be an example for other health workers. Need to do further research on other variables that affect the performance of outside variables examined in this study.

\section{ACKNOWLEDGEMENTS}

The authors would like to thank the team of researchers in Tuban and Lamongan, Indonesia. This research is not possible without the innovative work and dedication to improving the performance of nurses ponkesdes.

\section{REFERENCES}

[1] Gibson and Ivancevich, “Organization, Behavior, Structures,” Translated by: Zuhad Ichyaudin, Jakarta, Erlangga, 1996.

[2] F. C. Gomes, "Human Resources Management,” Yogyakarta, Andi Offset, 2003.

[3] Y. T. Keban, "Six Strategic Dimension of Public Administration, Concept, Theory and Issue,” Jakarta, Gava Media, 2004.3

[4] S. P. Robbins, "Organizational Behavior: Concept, controversy, Applications," Translated by: Hadyana Pujaatmaka, Jakarta, PT. Prenhalindo, 1996.

[5] A. Hamid, "The Influence of the Organization Culture, Motivation and Work Achievement in PT Nusantara IV Sumatera Utara,” Disertasi, Surabaya, Unair, 2002.

[6] Soedjono, "The Influence of the Organizational Culture to the Performance Organization and Job Satisfaction of Employees in the Public Passenger Terminal in Surabaya,” Jurnal Manajemen dan Kewirausahaan, vol/issue: 7(1), 2005.

[7] B. Sumardjoko, "The Contribution of the Leadership and Organization Culture through the Competencies of the role of the Lecturer in the Guarantee the Quality of PTS Residence in Surakarta," Jurnal Varia Pendidikan, vol/issue: 22(1), 2010. ISSN 0852-0976.

[8] Kotter and Heskett, “Corporate Culture and Performance," Translated by: Benyamin Molan, Jakarta, PT Prehalindo, 1998.

[9] Moeldjono, “Organizational Culture in the Challenge, Jakarta, PT Alex Media Komputindo, 2005. 
[10] A. P. Mangkunegara, "Behavior and Organizational Culture,” Bandung, Refika Aditama, 2008.

[11] Wibowo, "Organization Culture a Needs to Improve the Performance of the Long-term," Jakarta, PT. Raja Grafindo Persada, 2010.

[12] P. Tika, “Organization Culture and Improvement of the Company Performance,” Jakarta, PT. Bumi Aksara, 2006.

[13] A. L. Riani, “Organizational Culture,” Yogyakarta, Graham Ilmu, 2011. 